\title{
Can HRM Practices Improve Job Satisfaction of Ready Made Garment (RMG) Workers in Bangladesh? An Alternative Solution to Recent Unrest
}

\author{
Md. Atiqur Rahman Sarker $^{1} \&$ Rumana Afroze ${ }^{1}$ \\ ${ }^{1}$ Department of Business Administration, East West University, Bangladesh \\ Correspondence: Md. Atiqur Rahman Sarker, Department of Business Administration, East West University, \\ Bangladesh. E-mail: mars@ewubd.edu / sarker.limon@gmail.com
}

\begin{abstract}
Labor unrest in RMG sector of Bangladesh has become a major problem in trade and finance due to which organizations are losing their business. RMG workers are not so happy with their employers because of improper labor practices. However, employee's job satisfaction is an important factor for organizational success. Through HRM practices, organizations try to increase satisfaction among the employees for goal achievement. The objective of this study is to examine the relationship among financial, non financial HRM practices and job satisfaction of RMG workers in order to reduce unrest. For this study, 35 different RMG companies have been chosen on convenient basis around Dhaka, Gazipur and Narayanganj district of Bangladesh. This study adopts regress method under 200 questionnaires survey where data have been collected from both managerial and non managerial workers. Present study has found that both financial and non-financial job factors are making the workers satisfied, so that they are less likely to involve in labor unrest.
\end{abstract}

Keywords: financial and non financial HRM practices, job satisfaction, RMG workers in Bangladesh

\section{Introduction}

Practice of Human Resource Management (HRM) is getting more priority in this age of knowledge economy in order to remain competitive in global market. Employees are the key source of competitive advantage for business organization, as innovative and committed workers can make dramatic changes in business performance and sustainability (Agarwala, 2011; Nankervis \& Compton, 2002). Job satisfaction is such a tool that improves the motivation and commitment of workers which consequently leads to higher growth and productivity (Rubel \& Kee, 2013; Shabnam \& Sarker, 2012). Without satisfied employees, no organization can achieve their business target as unhappy workers will never work for progress and prosperity. On the other hand, job dissatisfaction raises worker's voice and creates unrest (Hossan etal., 2012a; Noe et al., 2007). Therefore, job satisfaction is essential to enhance peace and harmony at work place as well as to ensure higher productivity.

Ready Made Garment (RMG) is one of the successful manufacturing sectors with greater contribution to the national economy of Bangladesh (Hossan et al, 2012a; Chowdhury, et al, 2006). RMG is the main source of export for the last 25 years, and this sector employs more than 3 billion people in Bangladesh of whom $90 \%$ are poor and underprivileged women (Ahamed, 2014). However, job satisfaction of RMG workers in Bangladesh are decreasing at present time due to improper work practices that include insufficient salary, discrimination, unhealthy work environment, frequent work accidents and hazards (Aslam et al., 2011; Adbin, 2008; Berik \& Rodger, 2008; Hossan et al., 2012a; Hossan et al, 2012b). As a result, dissatisfied RMG workers in Bangladesh are creating unrest and raising voice in recent time. Due to labor unrest, RMG sectors are losing its market as unrest disrupts production functions and passes the message to the buyers regarding employee discrimination (Ahamed, 2014; Chowdhury, et al, 2006). Unrest in RMG is affecting business profit and prospect. Therefore, it is crucial to save this emerging industry by taking corrective action as early as possible. This paper is concentrating on reduction of labor unrest by improving job satisfaction. That is why this paper focuses on the importance and impact of HRM practices on job satisfaction among RMG workers.

\section{Theoretical Background on HRM and Its Importance}

Human Resource Management (HRM) refers to the policies and practices involved in carrying out the 'Human 
Resource (HR)' aspects of a management position including HR planning, job analysis, recruitment, selection, orientation, compensation, performance appraisal, training and development, and labor relations (Dessler, 2007; Khan, 2010). HRM is considered as critical organizational resource that helps an organization to remain competitive and sustainable (Lloyd \& Leslies, 2000; Marchington and Wilkinson, 2008; Schuler, 1990). It is one of the important area that influences a number of employee's attitudes and behavior such as intent to leave, levels of job satisfaction, and organizational commitment (Lee \& Heard, 2000; Sarker, 2014b).

HRM practices have an impact on operational performance as well as on employee commitment (Noe et al., 2007; Wright et al., 2003). The relationship between HRM practices and corporate turnover, profitability and market value are examined by Huselid (1995) where these are positively correlated. Guthrie (2001) examined the impact of HRM practices on turnover and productivity among employees in the context of New Zealand. He noted that HRM practices have impact on turnover, and when high-involvement HRM practices have been implemented then the relationship between retention and productivity is going to be positive. In addition to this, Delery and Doty (1996) found that, HRM practices were positively related to profitability. They also examined the relationship between HRM practices and profitability in a sample of commercial banks in the USA. The study of Absar et al. (2010) indicates that the factors like recruitment and selection, training and development, performance appraisal, and compensation management are independently and positively correlated with Organizational Performance (OP). Moreover the relationship between Performance Appraisal (PA) and compensation management is higher than the relationship between training and development and performance appraisal. This study also found the highest positive value of correlation between PA and OP, so that firms are required to give main focus on PA for getting remarkable organizational performance. Moreover, employee's commitment towards the organization and job satisfaction increase when employees judge the organization to be fair and supportive with regards to the availability and frequency of promotional opportunities, adequacy of pay, effective supervision, employer's consideration for worker's well being (Nasurdin et al., 2001; Sarker, 2014b; Shabnam \& Sarker, 2012). That ultimately reduces worker's job dissatisfaction.

\section{HRM Practices and Job Satisfaction}

Job satisfaction by definition is employee's sense of achievement and success that is directly linked to productivity and personal wellbeing (Ahamed, 2014; Miller \& Rosse, 2002). According to Spector (1997), job satisfaction is employee's interest and liking towards the work. It is the degree to which employees enjoy their works. Job satisfaction is associated with many organizational variables among which HRM practices are mostly important. Majumder (2012) studied on the relationship between employee's job satisfaction and various dimensions of HRM practices in the different private commercial banks. Nine major factors like Recruitment and Selection Systems, Compensation Package, Job Security, Career Growth, Training and Development, Management Style, Job Design and Responsibilities, Reward and Motivation, and Working Environment are followed by different private banks. The study reveals that most of the employees are not satisfied with their compensation package followed by reward and motivation, career growth, training and development, management style, and job design and responsibilities. If a person's work is interesting, pay is fair, promotional opportunities are good, his or her supervisor is supportive, and co-workers are friendly, then a situational approach leads one to predict worker is satisfied with their job (Brief, 2002; Taylor, 2008; Zaman et al., 2013).

Financial benefits and social welfare, security and leave provisions have a positive impact on worker's quality of work life. Moreover, non-financial and indirect work benefits like canteen facilities, festival bonus, attendance bonus, transport facilities and wage increment also have the positive role for workers quality of work life (Nasrudin et al., 2001; Zohir, 2007). As a result, employees become happy towards their work which in return improves job performance as well as organizational performance. The study of Rimi (2014) also revealed that quality of work life has a positive and significant relationship with employees' job satisfaction. Rimi (2014) mentioned that the items of employees job satisfactions were job safety \& security (workers are not afraid of losing job), adequate provident benefits, supportive supervisor, induction and training arrangements, consideration of worker's voice to top management, and availability of supportive tools and technology. It has been noticed that most of the variables have positive correlation with employees' satisfaction. As employee's job satisfaction is positively related to organizational performance, it is important that managers should try to develop a strong connection between quality of work life and employee job satisfaction through effective HRM practices.

\section{RMG Sector in Bangladesh}

Ready Made Garment (RMG) is one of the successful manufacturing sectors with greater contribution to the national economy of Bangladesh (Hossan, et al, 2012a; Chowdhury, et al, 2006). RMG is the main source of 
export for the last 25 years, and this sector employs more than 3 billion people in Bangladesh of whom $90 \%$ are poor and underprivileged women (Ahamed, 2014). This sector became important in terms of generating employment, foreign exchange earnings and its contribution to Gross Domestic Product (GDP) (Ahamed, 2014). This industry started its journey in the late 1970s, expanded heavily in the 1980s and boomed in the 1990s (Hossan, et al., 2012a, Robbani, 2000). The quick expansion of RMG was possible because of less complicated technology (easy to transfer), cheap machineries, large number of unemployed and poor female workers and comparatively cheap labor cost (Robbani, 2000).

Though RMG is a booming sector for national trade and finance, this sector is facing some challenges in building backward and forward linkages, managing transport for goods delivery due to the ineffective use of infrastructures, diversifying product lines and finding new market (Robbani, 2000). Besides that poor working conditions and work practices (like irregular pay) in the factories and a lack of social compliance are serious concerns in RMG sector, as these lead to frequent labor unrest (Hossan, et al, 2012a; Muqtada et al., 2002).

\section{Current Employee Management Problems of RMGs in Bangladesh}

The study of Hossan, et.al (2012a) found that the RMG factories in Bangladesh face high rate of temporary labor crisis because of high and frequent turnover and absenteeism rates. This study also found that high work-load, poor behavior of line managers, low skills and low wage rates are the notable reasons for high job turnover. Sometimes existing workers face extra work-load due to the shortage of labor, and this ultimately reduces their job satisfaction and work efficiency. One of the important causes behind labor unrest in RMG sector is poor wage structure of workers. Unrest by RMG workers due to irregular pay has become a common phenomenon in Bangladesh at present time.

There are some other issues like career path of the workers is not motivating because of limited scope for multi-skilling the workers (Hossan, et al., 2012b). Huda, et.al (2007) mentioned that the absence of Human Resource Development (HRD) functions in RMG, but it is crucial for organizational development. Moreover, workers do not get feedback based on their performance and wage rate is not proportionate with living cost (Ahamed, 2014). Pay discrimination also exits among male and female workers (Ahamed, 2014). Even though government has introduced minimum wage rate for RMG workers, but it is not followed by the employers as well as not well monitored by the law enforcement authorities (Absar, 2001; Ahamed, 2014; Rimi, 2014). Occupational health and safety crisis exist in RMG as frequent work accidents occurs, and the workplace is not safe and friendly for workers which often create stress and medical disorder (Rubel \& Kee, 2013; Sarker, 2014a) However, institutional reforms such as regulation and formulation of labor law are necessary to ensure worker's rights.

Another problem for RMG workers is work-family conflict, which is related with negative work outcomes such as job dissatisfaction, job burnout and turnover, psychological distress, work and family dissatisfaction (Ford et al., 2007 cited in Rimi 2014). Rimi (2014) proposed a model for reducing work family conflict through introducing family supportive HRM policy and also introducing person-organization fit in selection process in the study. This model also proposed some other factors like flexible job design, flexible work hour to help employees accommodate both job and family responsibilities, implementing family supportive facilities (child care, older care, parental leave, family medical coverage and physical facilities) for reducing work family conflict. Due to the some major incidents happened in the last few years like fire in the Tazreen Fashions factory (killed more than 110) and the collapse of the Rana Plaza garment factory building (killed over 1,100 people and more than 2,500 were injured), Bangladeshi RMG products are now losing its market in developed countries (Textile Bulletin, May, 2014). Recently the workers of 'Toba' garments factory in Dhaka (capital of Bangladesh) have raised their voice and joined the strike because of their unpaid salaries which are due for last three months (The Dhaka Tribune, 18 July, 2014; The Daily Star, 11 August, 2014). It is also reported that 124 RMG companies have failed to pay the regular salary and bonus before the 'Eid' festival which raises strike among the factory workers (Dhaka Tribune, 18 July, 2014). The USA has already suspended Bangladesh from the Generalized System of Preferences (GSP), which allows duty-free entry of over 5000 goods to the US market (Textile Bulletin, May, 2014).

\section{Objective and Methodology of the Study}

The objective of this study is to understand how the HR managers in 35 selected companies are working as a strategic partner to manage HRM activities, given the organization's strategic goals and objectives, to see usefulness and effectiveness of HRM practices, to criticize the system, and to suggest and recommend. Specific objectives are:

- $\quad$ To evaluate how the key job factors (Financial and Non-financial) are rated by employees; 
- To identify the significance of different variables affecting employee's evaluation of job satisfaction.

This study has used Multiple Regression Equation to identify the components known as dependent and independent variables and their relationship among one another and their impacts on the research. The Multiple Regression Equation is, $\mathrm{Y}=\mathrm{X} 1+\mathrm{X} 2$ where dependent variable $\mathrm{Y}$ is job satisfaction; and independent variables are X1 (Non-financial factors) and X2 (Financial factors). Through an initial exploratory research and literature, some factors have been identified. Workers consider the following factors for their job satisfaction

Table 1. Key factors for employee job satisfaction

\begin{tabular}{ll}
\hline Non-financial factor & Financial factor \\
\hline$>$ Clearly defined job description during recruitment and orientation & $>$ Salary \\
$>$ Unbiased evaluation of job performance & $>$ Promotion \\
$>$ Flexibility & $>$ Bonus \& incentives \\
$>\quad$ Training & Financial assistance like \\
$>\quad$ Job security & health care, sick leaves (with \\
$>$ Efficient and supportive line manager & payments) etc. \\
$>$ Good work environment etc. & \\
\hline
\end{tabular}

To do the analysis and establish the relationship, data has been collected from both managerial and non-managerial workers of 35 different RMG companies in Dhaka, Gazipur and Narayanganj districts of Bangladesh. 200 questionnaire surveys were done during June and August, 2014 for this study based on convenient sampling. This survey was flexible and informal and was open for all to answer based on their perception. Data were obtained by considering two types of HRM practices- financial and non-financial affecting RMG workers for their job satisfaction. A 5 point Likert Scale was used to question the respondents. The respondents were asked to rate on the scale between Strongly Agree and Strongly Disagree. Researchers designed 1 question to test the dependent variable (job satisfaction) based on the independent variables. For the independent variable these are the number of questions designed to test each factors from every angle. There are total 18 questions among which four were for financial factors and fourteen for Non-financial factors.

\section{Findings and Discussion}

\subsection{Reliability Test}

\subsubsection{Reliability Measurement for Independent Variable "Non-financial"}

The internal validity or consistency between each variable is denoted by the alpha value of 0.952 . This means the internal consistency among the multi-item questions is $95.2 \%$. So the internal consistency among the answer of the questions are very strong in terms of consistency and reliability.

\subsubsection{Reliability Measurement for Independent Variable "Financial"}

The internal validity or consistency between each variable is denoted by the alpha value of 0.880 . This means the internal consistency among the multi-item questions is $88.0 \%$. As the alpha values are closer to the Cronbach Coefficient Alpha, it does not need to delete any more items.

\subsection{Analysis Techniques}

Once the reliability analysis was done, mean value of independent variables was calculated. Finally, the analysis part was done through regression analysis in SPSS.

7.2.1 Hypothesis Testing on Independent Variable- Non-Financial Facility

$\mathbf{H}_{\mathbf{0}}$ : Non-financial facilities do not significantly influence Job satisfaction.

$\mathbf{H}_{1}$ : Non-financial facilities significantly influence Job satisfaction. 
Table 2. Model summary

\begin{tabular}{lllll}
\hline & & & & Std. Error of the \\
Model & $\mathrm{R}$ & R Square & Adjusted R Square & Estimate \\
\hline 1 & $.805^{\mathrm{a}}$ & .647 & .628 & .623 \\
\hline
\end{tabular}

Note. a. Predictors: (Constant), nonfinancial.

Table 3. Coefficients ${ }^{\mathrm{a}}$

\begin{tabular}{lllllll}
\hline & & \multicolumn{2}{l}{ Unstandardized Coefficients } & \multicolumn{2}{c}{ Standardized Coefficients } & \multicolumn{2}{c}{ Sig. } \\
\cline { 3 - 5 } Model & & $\mathrm{B}$ & Std. Error & Beta & $\mathrm{t}$ & \\
\hline 1 & (Constant) & -.576 & .791 & & -.728 & .476 \\
& nonfin & 1.142 & .199 & .805 & 5.747 & .000 \\
\hline
\end{tabular}

Note. a. Dependent Variable: Q9.

The observed table shows that Non-financial activity has a positive influence $(\beta=0.805)$ regarding job satisfaction. This means that Non-financial activity has a directly proportional relation with the dependent variable; if one increases the other also increases and vice versa. This means that the variable "Non-financial activity" has around $80 \%$ influence of the dependent variable. We can see that $\mathrm{P}$ value (.000) explains the significance level or percentage of error. Here, we see no error is present.

So, Non-financial activity has significant positive influence on Job satisfaction.

\section{Decision:}

$\mathrm{H}_{1}$ is accepted and Ho null hypothesis is rejected.

7.2.2 Hypothesis Testing on Independent Variable- Financial Facility

$\mathbf{H}_{\mathbf{0}}$ : Financial facilities do not significantly influence Job satisfaction.

$\mathbf{H}_{\mathbf{1}}$ : Financial facilities significantly influence Job satisfaction.

Table 4. Model summary

\begin{tabular}{|c|c|c|c|c|}
\hline Model & $\mathrm{R}$ & R Square & Adjusted R Square & $\begin{array}{l}\text { Std. Error of the } \\
\text { Estimate }\end{array}$ \\
\hline 1 & $.707^{\mathrm{a}}$ & .500 & .473 & .741 \\
\hline
\end{tabular}

Note. a. Predictors: (Constant), financial.

Table 5. Coefficients ${ }^{\mathrm{a}}$

\begin{tabular}{|c|c|c|c|c|c|c|}
\hline \multirow[b]{2}{*}{ Model } & & \multicolumn{2}{|c|}{ Unstandardized Coefficients } & \multirow{2}{*}{$\begin{array}{l}\text { Standardized } \\
\text { Coefficients } \\
\text { Beta }\end{array}$} & \multirow[b]{2}{*}{$\mathrm{T}$} & \multirow[b]{2}{*}{ Sig. } \\
\hline & & $\mathrm{B}$ & Std. Error & & & \\
\hline \multirow[t]{2}{*}{1} & (Constant) & .615 & .791 & & .777 & .447 \\
\hline & Fin & .834 & .197 & .707 & 4.246 & .000 \\
\hline
\end{tabular}

Note. a. Dependent Variable: Q9.

The observed table shows that Financial activity has a positive influence $(\beta=0.707)$ regarding job satisfaction. This means that financial activity has a directly proportional relation with the dependent variable; if one increases the other also increases and vice versa. This means that the variable "Financial Activity" has around 70\% influence of the dependent variable. We can see that $\mathrm{P}$ value (.000) explains the significance level or percentage of error. Here, we see no error is present.

So, Financial activity has significant positive influence on Job satisfaction. 


\section{Decision:}

$\mathrm{H}_{1}$ is accepted and Ho null hypothesis is rejected.

7.3 Regression Analysis

Table 6. Model summary

\begin{tabular}{llllll}
\hline & & & & Std. Error of the \\
Model & $\mathrm{R}$ & R Square & Adjusted R Square & Estimate & \\
\hline 1 & $.811^{\mathrm{a}}$ & .657 & .617 & .632 &
\end{tabular}

Note. a. Predictors: (Constant), nonfin, fin.

From the regression analysis, it has been found that the Value of R Square is (.657). That means, independent variables (Non-financial and Financial activity) has $65.7 \%$ impact over the dependent variable (Job satisfaction). In other words, the dependent variable can be influenced $65.7 \%$ by the independent variables.

\subsection{Discussion}

In this study, researchers tried to find out the factors which affect the employee's performance while working in RMG companies. The 2 factors (Non-financial and financial HRM practices) are tested by conducting a regression analysis. The result of regression analysis indicates that both of these two factors (financial and non-financial HRM practices) have significant influence on job satisfaction. Result can also be verified by aligning the survey results with the regression analysis.

From Fig: 1, the financial and non-financial assistance of the company has positive and parallel relation with the job satisfaction as the average answers of both the variables were close to 4 (agreed to be satisfied with the jobs and benefits). As the independent variable (financial \& non-financial assistance) increases, dependent variable also increases (Job satisfaction).

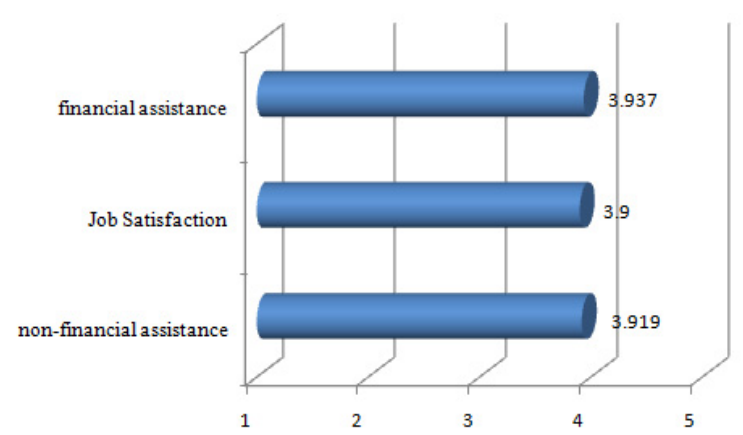

Figure 1. Average result of 5 point likert scale

It can also conclude that the independent variables have positive influence over the dependent variable and they have a harmonious relation among them.

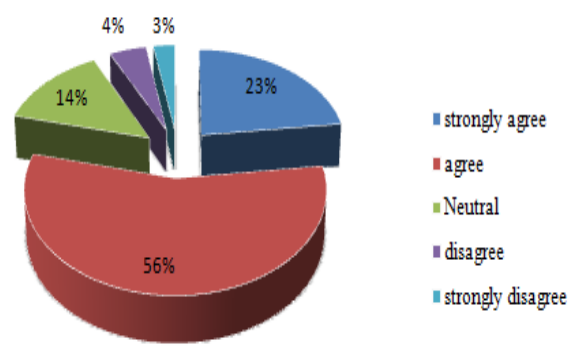

Figure 2. 56\% agreed to be satisfied with non-financial practice in their RMG company 
From the above pie chart (Fig 2) it can be said that most of the employees have agreed that they are satisfied with the non-financial practices (unbiased evaluation of job performance, flexibility, training, job security, proper treatment of the supervisor, good work environment etc) of their company which increases their job satisfaction.

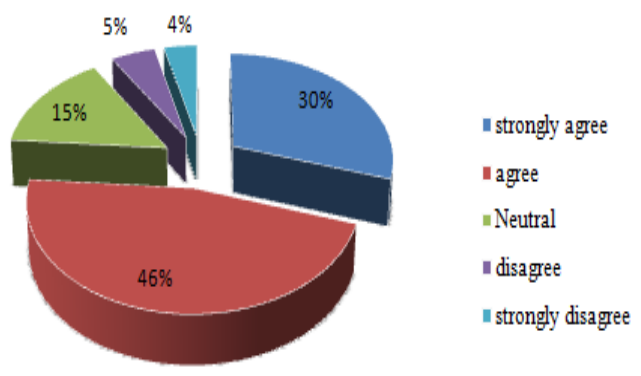

Figure 3. $46 \%$ agreed to be satisfied with the financial practice in their RMG company

From the above pie chart (Fig 3), it can conclude that most of the employees have agreed that they are satisfied with the financial practices (salary, bonus, promotion, health-care etc) of their company that results in their job satisfaction. Both of the independent variables are equally important to increase the satisfaction level of the employee working in RMG sector.

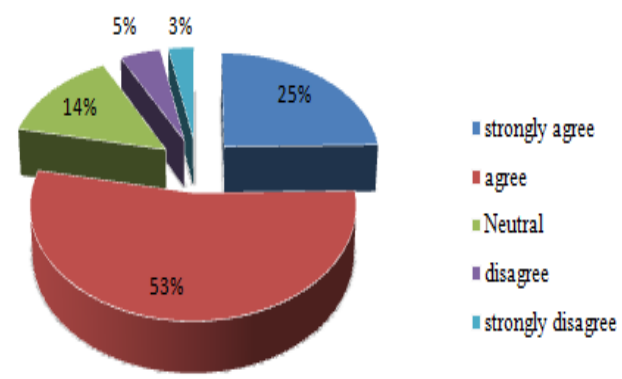

Figure 4. Maximum agreed (53\%) to be satisfied with their job (dependent variable)

After all these analysis, it can be stated that both financial and non-financial benefits are making the employee to be satisfied with their current job.

\section{Conclusion and Recommendation}

Human Resource Management is not a very old concept in Bangladesh. Due to the expansion of MNC business and NGO activities, HRM is now getting more priority in order to maintain legal compliances. On the other hand, RMG sector in Bangladesh is contributing major role play to the economy because of high sales volume in foreign market (Ahamed, 2014; Rubel \& Kee, 2013). But this sector is facing business challenges due to the suspension of the Generalized System of Preferences (GSP). Some accidents in RMG sector (like Rana Plaza Collapse; firing in Tazreen Fashions) are creating health and safety crisis. As the working condition of this sector is getting worst, employees' involvement in labor unrest has been increased. However, the main reason behind this unrest is employee's job dissatisfaction in absence of proper financial and non financial job factors. This study has found that both financial and non financial job factors are related with job satisfaction of the workers in RMG sector. If the organization can provide appropriate financial and non financial benefits to the employees, they are going to be satisfied and also less likely to involve in labor unrest. Therefore, it can be concluded that job satisfaction through proper HRM practices can be an alternative solution for reducing unrest in RMG sector of Bangladesh.

From this research based on the survey in different RMG factories, following observations and suggestions are given for further management development in RMG sector: 
- Most of the RMG companies in Bangladesh do not have formal recruitment and selection program and they do not organize any orientation program. Therefore, workers do not get any idea about the business and its goal when they start their job. At the same time, employees do not understand what is expected from them by their employers. RMG organization should follow a formal recruitment, selection and orientation programs.

○ Every organization should have fair job appraisal method and they should take exit interview in order to retain talented workers and also to find out the reasons of job turnover.

○ In this research, it is also identified that only few RMG employers ensure proper medical \& health care facilities. Therefore, employers must focus in this area in order to ensure health care facilities for the workers.

- To balance between work and family life, employers must ensure friends and family related benefits (like day care facilities, subsidized meal at staff canteen, transportation facilities and so on).

- As majority of RMG workers in Bangladesh are female, organization should understand their family needs and offer all ranges of work related benefits including maternity leave with full payment, separate sanitation facility, flexible work schedule, work place safety and security.

- From this research, it is found that not only financial facilities but also the non-financial facilities are equally important to increase job satisfaction. Therefore, special consideration should be given to non-financial HRM activities.

○ RMG companies should follow Equal Employment Opportunity compliance and equity to avoid legal challenges in case of any discrimination.

\section{References}

Abdin, M. J. (2008). Overall Problems and Prospects of Bangladeshi Ready-Made Garment Industry. Retrieved from http://ssrn.com/abstract=1117186

Absar, S. S. (2001). Problems Surrounding Wages: Readymade Garments Sector in Bangladesh. Labour and Management in Development, 2(7), 2-17.

Absar, M. M. N., Azim, M. T., Balasundaram, N., Akhter, S. (2010). Impact of Human Resources Practices on Job Satisfaction: Evidence from Manufacturing Firms in Bangladesh. Petroleum-Gas University of Ploiesti, Bulletin, 12(2), 31-42.

Ahamed, F. (2014). Job Dissatisfaction in the Bangladesh Ready Made Garment Sector- To What Extend HR/IR Practices Can Grow Exhilaration of RMG Workers? International Journal of Business and Management Review, 2(1), 1-12.

Agarwala, T. (2011). Strategic Human Resource Management (11th ed.). Oxford: New Delhi.

Aslam, R., Shumaila, S., Azhar, M., \& Sadaqat, S. (2011). Work Family Conflicts: Relationship between Work Life Conflict and Employee Retention A Comparative Study of Public and Private Sector Employees. Working Paper. Hailey College of Commerce, University of the Punjab, Lahore, Pakistan. http://dx.doi.org/10.1596/1813-9450-5669

Berik, G., \& Ridger, Y. (2008). Options for Enforcing Labor Standards: Lessons from Bangladesh and Combodia. Department of Economics Working Paper Series. University of Texas Arlington, USA. Working Paper No. 2008-14.

Brief, A. P. (2002). Organizational Behavior and Human Decision Processes, 86(1), $131-139$. http://dx.doi.org/10.1006/obhd.2001.2975

Chowdhury, M. A., Ali, M., \& Rubba, R. (2006). WTO, Post-MFA Era and the Bangladesh RMG Sector: An Assessment of Performance and Challenges. South Asian Journal of Management.

Delery, J. E., \& Doty, D. H. (1996). Modes of Theorizing in Strategic Human Resource Management: Test of Universalistic Contingency, and Configurational Performance Predictions. The Academy of Management Journal, 39(4), 802-835. http://dx.doi.org/10.2307/256713

Dessler, G. (2007). Human Resource Management. Prentice Hall of India Private Limited, New Delhi.

Guthrie, J. (2001). The management, measurement and the reporting of intellectual capital. Journal of Intellectual Capital, 2(1). http://dx.doi.org/10.1108/14691930110380473

Hossan, C. G., Sarker, A. R., \& Afroze, R. (2012b). An Assessment of Managerial Skills in the Labour Intensive Industry: A Case Study of a Garments Manufacturing Firm. Journal of Accounting, Business and Management (JABM), 19(2). 
Hossan, C. G., Sarker, A. R., \& Afroze, R. (2012a). Recent unrest in RMG sector of Bangladesh: Is this an outcome of Poor Labour Practices? International Journal of Business and Management, 7(3). http://dx.doi.org/10.5539/ijbm.v7n3p206

Huda et al. (2007). HRM Practices and Challenges of Non-government Development Organisation: An Empirical Study on Bangladesh. Journal of Management, 9(1), 35-49.

Huselid. (1995). The Impact of Human Resource Management Practices on Turnover, Productivity and Corporate Financial Performance. Academy of Management Journal, 38(3), 635-672. http://dx.doi.org/10.2307/256741

Khan, M. A. (2010). Effects of Human Resource Management Practices on Organisation Performance: An Empirical Study of Oil and Gas Industry in Pakistan. European Journal of Economics, Finance and Administrative Sciences, 24, 158-175.

Lee, S. H., \& Heard, A. (2000). A managerial perspective of the objectives of HRM practices in Singapore: an exploratory study. Singapore Management Review, 22, 65-82.

Lloyed, L. B., \& Leslie, R. (2000). Human Resource Management (6th ed.). Irwin user page, McGraw-Hill, North America.

Majumder, M. T. H. (2012). Human Resource Management Practices and Employees Satisfaction Towards Private Banking Sector in Bangladesh. International Review of Management and Marketing, 2(1), 52-58.

Marchington, M., \& Wilkinson, A. (2008). Human Resource Management at work: People management and development (4th ed.). CIPD: London.

Miller, H., \& Rosse, J. (2002). Emotional reserve and adaptation to job dissatisfaction. The psychology of work: theoretically based empirical research. Hillsdale, NJ: Erlbaum.

Muqtada, M., Singh, A. M., \& Rashid, M. A. (2002). Bangladesh: Economic and Social Challenges of Globalization. The University Press Limited, Dhaka, Bangladesh.

Nasurdin A. M., Ramayah, T., \& Osman, M. (2001). Job Satisfaction and Organizational Commitment among the Malaysian Workforce, Malaysian Publications: April 2006.

Nankervis, A., \& Compton, R. (2002). Strategic Human Resource Management (4th ed.). Thomson: Victoria, Australia.

Noe, R. A., Hollenbeck, J. R., Gerhart, B., \& Wright, P. M. (2007). Human Resource Management: Gaining a competitive advantage. McGraw-Hill: USA.

Rimi N. N. (2014). Achieving Balance in Work-Family Conflict through the Influences of Family Supportive HRM: A Conceptual Framework for the Organizations of Bangladesh. International Journal of Business and Innovation, 1(3).

Robbani, M. G. (2000). World trade organisation and the readymade garment industry of Bangladesh: a critical analysis. Journal of Business Studies, 2(2), 16-27.

Rubel, M. R. B., \& Kee, D. M. (2013). Inside the Ready-Made Garment (RMG) Industry: The Role of Percieved Support on Employee Performance. Middle-East Journal of Scientific Research, 18(7), 1023-1034.

Sarker, A. R. (2014b). Increasing employee job satisfaction as well as organisational performance through effective HRM practices in private commercial banking sector of Bangladesh. Journal of Economics and Sustainable Development (JESD), 5(10).

Sarker, A. R. (2014a). Occupational Health and Safety (OHAS) crisis in tanneries of Bangladesh: Is this the violation of labor rights? European Journal of Business and Management (EJBM), 6(16).

Schuler, S. (1990). Repositioning the human resource function: Transformation or demise? Academy of Management Executive, 4(3), 49-60.

Shabnam, S., \& Sarker, A. R. (2012). Impact of CSR and Internal Marketing on Employee Job Satisfaction and Organisational Commitment: A Case Study from Export-Oriented SMEs in Bangladesh. World Journal of Social Sciences, 2(7).

Spector, P. E. (1997). Job Satisfaction: application, assessment, cause, and consequences. London: Sage press. Taylor, S. (2008). People Resourcing (4th ed.). CIPD: London.

Textile, B. (2014). Retrieved from http://textilebulletin.com/present-situation-rmg-sector-bangladesh-2013 
The Dhaka Tribune. (2014). Retrieved from http://www.dhakatribune.com/bangladesh/ 2014/jul/18/unrest-may-erupt-rmg-sector-over-payment-eid

The Daily Star. (2014). Retrieved from http: //www.thedailystar.net/ tags/readymade \%20garments\%20workers

Wright et al. (2003). The Impact of HR Practices on the Performance of Business Units. Human Resource Management Journal, 13(3), 21-36. http://dx.doi.org/10.1111/j.1748-8583.2003.tb00096.x

Zaman, L, Samina, Q. S., \& Sarker, A. R. (2013). Benefits of Training Need Analysis: A Case on Local Private Commercial Bank in Bangladesh. The Jahangirnagar Journal of Finance \& Banking, 1, 27-35.

Zohir, S. C. (2007). Role of Dhaka Export Processing Zone: Employment and Empowerment. Research Report, Bangladesh Institute of Development Studies.

\section{Copyrights}

Copyright for this article is retained by the author(s), with first publication rights granted to the journal.

This is an open-access article distributed under the terms and conditions of the Creative Commons Attribution license (http://creativecommons.org/licenses/by/3.0/). 